Telegraphic Realis m 



\section{Telegraphic Realism}

Victorian Fiction and Other Information Systems

R I CHARD MENKE

Stanford University Press

Stanford, Califoria

2008 
Stanford University Press

Stanford, California

(C) 2008 by the Board of Trustees of the Leland Stanford Junior University. All rights reserved.

No part of this book may be reproduced or transmitted in any form or by any means, electronic or mechanical, including photocopying and recording, or in any information storage or retrieval system without the prior written permission of Stanford University Press.

Printed in the United States of America on acid-free, archival-quality paper

Library of Congress Cataloging-in-Publication Data

Menke, Richard.

Telegraphic realism : Victorian fiction and other information systems / Richard Menke.

p. $\mathrm{cm}$.

Includes bibliographical references and index.

ISBN 978-0-8047-569I-4 (alk. paper)

I. English fiction-19th century-History and criticism.

2. Communication in literature. 3. Technology in literature.

4. Telecommunication in literature. 5. Telegraph in literature.

6. Postal service in literature. 7. Realism in literature. 8. Communication and technology—Great Britain-History—Igth century. I. Title.

PR878.C636 4462008

$823^{\prime} .809356-\mathrm{dc2} 2$

2007008106

This book was published with the assistance of the Willson Center for Humanities and Arts at the University of Georgia. 